\title{
Nonsteroidal anti-inflammatory drugs and inflammatory bowel disease
}

\author{
IngVAR BJARNASON, MSc, MD, MRCPATH, ANDREW MACPHERSON, MD, PHD, MRCP, \\ Sivagrunathan SOMASLINDARAM, PHD, KaTHY TEAHON, MD, MRCPI
}

I Bjarnason, A MacPherson, S SOMAslindaram, K TEAHON. Nonsteroidal anti-inflammatory drugs and inflammatory bowel disease. Can J Gastroenterol 1993;7(2):160-169. Nonsteroidal anti-inflammatory drugs (NSAIDs)adversely affect the entire gastrointestinal tract. The small intestinal side effects of NSAIDs are well-characterized and are a source of bleeding and protein loss which contributes to iron deficiency and hypoalbuminemia, respectively. NSAIDs rarely cause strictures, but these may be pathognomic when they occur. There are only isolated reports of small intestinal perforations and massive bleeding. The pathogenesis of NSAID enteropathy can be divided into two stages. The first stage is characterized by specific biochemical damage, principally to enterocyte mitochondria, followed by inhibition of generation of reparative prostaglandins. Collectively this causes a breach in mucosal integrity with increased intestinal permeability, which leads to the second, nonspecific tissue stage, representing an interplay between luminal aggressive factors and mucosal defences. This results in inflammation and macroscopic damage. The large intestine is not subjected to the same type of damage, presumably because of the completeness of drug absorption from the small intestine. However, NSAIDs have been implicated in colonic perforations and bleeding, diverticulitis and occasionally colitis. NSAIDs are recognized as one of four main causes of relapse in inflammatory bowel disease (IBD), all of which may have the potential to increase intestinal permeability. Extensive studies in patients with Crohn's disease - including sequential changes in intestinal inflammation, intestinal permeability and T cell activation in response to treatment with elemental diets, along with comparative studies on the site of neutrophil chemoattractants in IBD and NSAID enteropathy - suggest that the clinical spectrum of Crohn's disease can be viewed as two separate events. It is suggested that the relapse of Crohn's disease (with its unchecked inflammation) involves mechanisms identical to the nonspecific second stage of NSAID enteropathy, fundamentally unrelated to the

Departments of Clinical Biochemistry and Medicine, King's College School of Medicine and Dentistry, London, UK

Correspondence and reprints: Dr Ingvar Bjarnason, Department of Clinical Biochemistry, King's College School of Medicine, Bessemer Road, London SE5 9PJ, United Kingdom. Telephone (071) 2746222 ext 4108
$\mathrm{L}$ ITTLE PROGRESS HAS BEEN MADE in the understanding of the etiol. ogy and pathogenesis of ulcerative colitis and Crohn's disease (1). The vascular involvement in inflammatory bowel disease (IBD) and the demonstration of Mycobacterium species in a few patients with Crohn's disease ap. pear at best to be an epiphenomenon (2-6). More recently, however, there have been major advances in the development of immunological techniques to measure various pro- and antiinflammatory mediators. The application of these techniques in patients with IBD is providing much informa. tion on the action and interaction of inflammatory cells $(7,8)$. One particularly important offspring of this work is the idea of a multistage framework for the pathogenesis of IBD. Accordingly, Stenson $(9,10)$ suggested that the cause of inflammatory bowel disease, be it a microbe or toxin, leads to an acute inflammatory reaction, with subsequent secondary amplification by the neutrophils themselves. Hence disease relapse, defined as in. creased neutrophil accumulation (acute inflammation), should be due to enhanced exposure to the offending agent. Sartor (11) formulated a more 
cause of Crohn's disease. The basic cause may be found by exploring the mechanism for the inappropriate severity of the acute inflammatory response to luminal aggressive factors.

Key Words: Arthritis, Drug reaction, Inflammatory bowel disease, Intestinal inflammation, Permeability, Small intestinal disease

\section{Anti-inflammatoires non stéroïdiens et maladie inflammatoire de l'intestin}

RÉSUMÉ: Les anti-inflammatoires non stéroïdiens (AINS) affectent négativement les voies digestives dans leur ensemble. Leurs effets secondaires sur le petit intestin sont bien caractérisés et provoquent des saignements et des pertes protéiques qui contribuent à un déficit ferrique et à une hypo-albuminémie respectivement. Les AINS causent rarement des rétrécissements, mais ces derniers peuvent être indicateurs lorsqu'ils se produisent. Il n'y a que quelques rapports isolés sur des perforations du petit intestin et des hémorragies massives. La pathogenèse de l'entéropathie aux AINS peut être divisée en deux étapes: le premier stade est caractérisé par une lésion biochimique spécifique, principalement au niveau des mitochondries de l'entérocyte, suivie par une inhibition de la production de prostaglandines réparatrices. Ensemble, ces phénomènes provoquent une lésion de la muqueuse avec perméabilité intestinale accrue amenant la deuxième étape tissulaire non spécifique qui représente une interaction entre les facteurs agressants de la lumière et les mécanismes de défense muqueux. Cela résulte en une inflammation et en une lésion macroscopique. Le gros intestin n'est pas sujet aux mêmes types de lésions, probablement à cause du fait que le médicament est complètement absorbé dès le petit intestin. Cependant, les AINS ont été associés à des perforations coliques et à des hémorragies, à des diverticulites et occasionnellement à la colite. Les AINS sont reconnus comme lune des quatre principales causes de rechute de la maladie intestinale inflammatoire qui sont toutes dotées d'un potentiel à l'égard de l'augmentation de la perméabilité de l'intestin. Des études élaborées chez des patients atteints de maladie de Crohn, y compris des modifications séquentielles de l'inflammation intestinale, de la perméabilité intestinale et de l'activation des cellules $\mathrm{T}$ en réponse au traitement avec des diètes élémentaires, de même que des études comparatives localisées, des attractifs chimiques des neutrophiles dans la maladie inflammatoire de l'intestin et l'entéropathie aux AINS suggèrent que le spectre clinique de la maladie de Crohn puisse être perçu en deux phénomènes distincts. Il est suggéré que la récidive de la maladie de Crohn (avec son inflammation non contrôlée) met en jeu des mécanismes identiques à ceux de la deuxième étape non spécifique de l'entéropathie aux AINS, fondamentalement indépendants de la cause de la maladie de Crohn. La cause fondamentale peut être trouvée par l'exploration des mécanismes de la réaction inflammatoire aiguë excessive aux facteurs qui agressent la lumière.

comprehensive framework for the pathogenesis of Crohn's disease and proposed a genetically determined inability to down regulate the immunologic or inflammatory response to peptidoglycans and other luminal bacterial products. He suggests that intermittent breaches in intestinal mucosal integrity (increased intestinal permeability) causes a self-perpetuating unchecked inflammatory response with granuloma formation. At the same time it has become clear that nonsteroidal anti-inflammatory drugs (NSAIDs) a substantial number of patients (60 to $70 \%$ ) who receive them long term (12. 19). While it has been suggested that NSAID enteropathy may be a model for Crohn's disease $(20,21)$, other studies $(22-25)$ have implicated NSAIDs as an important cause of relapse of IBD. The elucidation of the effects of NSAIDs on small intestinal function and the pathogenesis of NSAID enteropathy with direct comparison with the pathophysiology of Crohn's disease has allowed insight into the possible cause small intestinal inflammation in mechanisms of relapse of the disease. Collectively the data suggest that Sartor's and Stenson's proposals can be condensed into a single theory in which the relapse of Crohn's disease differs fundamentally from the primary cause of the disease. A review of the studies that support this statement follows.

\section{EFFECTS OF NSAIDs ON PRE-EXISTING IBD}

Initially it was suggested that NSAIDs may be therapeutically important in patients with ulcerative colitis because the diseased mucosa produced increased amounts of prostaglandins. Although initial results looked encouraging, the consensus has emerged that rectally administered NSAIDs have a detrimental effect on the colitis (2629). Indeed, NSAIDs may be an important precipitant of relapse in patients with IBD (22-25). Kaufman and Tobin (22) documented relapses in totally quiescent disease following NSAIDs and suggested that this occurs within a few days of NSAID administration. Gastroenterologists who work closely with rheumatologists noted that although the arthritis of inflammatory bowel disease is often well controlled with NSAIDs these patients often have chronically active intestinal disease which is difficult to treat. The perceived wisdom is that bad colitis leads to arthritis (30). Conversely the colitis may be resistant to treatment because of NSAID administration for arthritis.

\section{THE EFFECT OF NSAIDs ON THE NORMAL LARGE INTESTINE}

There are only isolated case reports of orally administered NSAIDs causing colitis - namely naproxen, ibuprofen (three cases), and piroxicam (two cases) (31-33). There are two cases of acetylsalicylic acid causing colitis in patients with severe asthma $(34,35)$. However, there is a disproportionately large number of patients described with fenemate- (a weak inhibitor of cyclooxygenase) induced colitis, the only NSAID that commonly is associated with diarrhea $(36-41)$. Still, a retrospective uncontrolled epidemiological 
review suggested that a significant number of patients with large bowel bleeding or perforation admitted to hospital were on NSAIDs (42). Mielants et al (43-45), however, found no colonic damage on colonoscopy in over 250 patients on NSAIDs.

Rectally administered NSAIDs frequently cause problems, with 10 to $30 \%$ of patients experiencing distressing side effects. It may lead to nonspecific colitis, ulceration and strictures (46-50).

\section{THE EFFECT OF NSAIDS ON THE SMALL INTESTINE}

Along with the stomach and duodenum, the small intestine bears the main brunt of NSAID-induced toxicity. While the gastroduodenal mucosal complications may lead to life threatening complications contributing to the premature death of 3000 to 4000 people in the United Kingdom annually (51-53), the small-intestinal side effects are much more subtle. Nevertheless 60 to $70 \%$ of patients on NSAIDs for over six months have evidence of small intestinal inflammation (12-19). NSAID enteropathy is defined on the basis of small intestinal localization of indium-111 labelled neutrophils and their four day fecal excretion. The technique is particularly well suited for the investigation of inflammation because it uses the specific homing chemoattractive properties of neutrophils. The neutrophils migrate to the intestine (or other organs) only in response to specific chemoattractants. This is the final outcome of a series of complex events, namely adherence, aggregation, orientation and locomotion, in response to a specific stimulus and it does not take place by passive means (54-57). Ignoring these aspects of neutrophil function leads to erroneous interpretations, such as that neutrophil exudate is a nonspecific passive phenomenon.

NSAID enteropathy is a low grade inflammatory reaction. The prevalence does not vary with the type of NSAID nor does the severity (as quantitated with the fecal excretion of indium-111 over four days), both of which are unrelated to gender or age $(11,12,19)$. Six patients on NSAIDs who have had gastric resections, however, had severe enteropathy (fecal excretion 8 to $18 \%$ ), suggesting that either the protective effect of gastric acid upon small bowel colonization of bacteria or the rapid and complete delivery of NSAID is important in the pathogenesis of the inflammation (unpublished data).

The clinical implications of NSAID enteropathy are questionable at first sight because patients have no clear cut symptoms, and serious bleeding or perforations from the small intestine are rare. NSAIDs, however, occasionally cause small intestinal strictures (5865). The pathology may be characteristic, if not pathognomic, for NSAIDs and is termed diaphragm disease (18). These are multiple (three to 70 ), thin ( 2 to $4 \mathrm{~mm}$ ), concentric, septate-like mucosal projections that narrow the lumen to 0.1 to $2 \mathrm{~cm}$. They are mainly located in the midsmall intestine (one report describes them in the cecum and ascending colon) and are characterized histologically by prominent submucosal fibrosis with no evidence of vascular involvement (66). These appear to represent one end of a spectrum of NSAID-induced strictures, the other extreme being single fibrotic, broad based, ulcerative lesions similar to those described in patients on certain potassium preparations.

It is also clear that the same 60 to $70 \%$ of patients on NSAIDs with the enteropathy have small intestinal bleeding as a consequence. The magnitude of the bleeding is similar to that in patients with gastric or colonic malignancies (67) and will contribute to the iron deficiency which is so common in patients with rheumatoid arthritis on NSAIDs $(15,17,19)$. In addition, most patients have a mild proteinlosing enteropathy which occasionally is sufficiently severe to cause hypoalbuminemia. The elucidation of a small intestinal origin of iron deficiency and hypoalbuminemia may offer new therapeutic approaches for these complications; particularly important because hypoalbuminemia, which affects $10 \%$ of all hospitalised rheumatoid patients, is associated with significant morbidity and is difficult to treat at present. The mechanism of the inflam- mation and the complications are of considerable interest. However, it is important to re-emphasise that the neutrophil chemotaxis, red cell loss and protein loss cannot be explained on the basis of oozing of blood or frank bleed. ing. In NSAID enteropathy, 1 to $18 \%$ (mean $3 \%$ ), of the labelled neutrophils are excreted in feces. If this were simply a reflection of bleeding, the amount of blood lost would equal excretion of white cells, eg, for a $3 \%$ white cell loss there would be a $3 \%$ loss of whole blood, which amounts to $150 \mathrm{~mL}$ in a normal average man. This exceeds that measured by an order of magnitude of 1 to $10 \mathrm{~mL} /$ day (NSAID enteropathy). Additionally, as neutrophils are much larger than red cells, these findings can. not be explained on the basis of vascular leakiness or extravasation. Indeed to appreciate the pathophysiology of NSAID enteropathy fully, it is necessary to keep in mind the basic function of neutrophils. Given that neutrophils only migrate in response to specific neutrophil chemoattractants (micro. bial, damaged cells, etc) the sequence of events when they come into contact with the chemoattractant are predetermined, ie, burst generation of oxygen. free radical species followed by internalisation of the chemoattractant for enzymatic degradation (54-57). If the quantity of chemoattractant is sufficient, the neutrophil disintegrates with further catheptic enzyme release. Both mechanisms serve to destroy the chemoattractant, but also cause indiscriminate damage to the immediate surroundings of the neutrophil. In theory it would seem that if this oc. curred within the mucosa there would be evidence of tissue damage as assessed by protein or blood loss. If, on the other hand, the neutrophil was seeking a luminal chemoattractant, it would remain in an unactivated state during its passage from the circulation and across the intestinal mucosa. In reality there is good experimental evidence that this is the case, as neutrophils seek. ing a luminal chemoattractant do not cause much mucosal damage but if given intracutaneously, an intense in. flammatory reaction occurs $(68,69)$.

In NSAID enteropathy there is evi- 
dence that the bleeding (and, by analogy, the protein loss) is a consequence of neutrophil activation within the mucosa (70) because studies show that while the fecal excretion of neutrophils is disproportionally greater than the intestinal blood loss, there is a significant correlation between the two when simultaneously assessed in the same patient.

\section{PATHOGENESIS OF NSAID ENTEROPATHY}

In humans, small intestinal inflammation is evident only after six months of consistent NSAID ingestion. Nevertheless, increased small intestinal permeability occurs within hours of taking the drug. The immediate effect of increased intestinal permeability is uncertain (71-78). The lactulose/ L-rhamnose and mannitol ${ }^{51}$ CrEDTA permeability tests assess the small intestinal function to act as a barrier to the permeation of hydrophilic macromolecules which cannot traverse the brush border membrane because of their size and solubility characteristics (79). The tests assess the integrity of the intercellular junctions, which are susceptible to damage by various means, much more so than the enterocytes themselves. It seems that increased intestinal permeability to ${ }^{51}$ CrEDTA or lactulose increases the likelihood of macromolecular permeation. Certainly in experimental situations there is a good correlation between macromolecular absorption and increased intestinal permeability (80-82). NSAID-induced increased intestinal permeability may relate to drug potency to inhibit cyclo-oxygenase. This is only partially prevented by concomitant prostaglandin administration (and then only at very large doses) (7173). Pro-NSAIDs that are activated only following drug absorption do not increase intestinal permeability, suggesting that most of the damage occurs during drug absorption $(77,83)$. This is, however, a controversial issue because rectally administered NSAIDs increase small intestinal permeability in humans (71). A glucose and citrate formulation of indomethacin is particularly effective in preventing the permeability changes caused by indomethacin in the short term, indicating that some of the damage is not related to its effect on prostanoid metabolism (78). This is borne out in experimental animals where the pathogenesis is better understood; NSAIDs appear to uncouple mitochondrial oxidative phosphorylation with resulting biochemical evidence of brush border damage and a compensatory inrease in mitochondrial biogenesis (84-86) before any macroscopic damage is evident. Bile and bacteria are both important in the development of macroscopic damage and ulcers in the rat, which implies that bile may perturbate the damaged cell membrane and that the normal small intestinal flora gains access to the mucosa, where it elicits a neutrophil chemoattractive response (78-92). Certainly the prevalence of ulcers is much reduced in the germ-free rat and in situations where neutrophil migration is prevented $(93,94)$ (eg, neutropenia, inhibition of leucocyte adhesion, etc). Neither observation is unique for NSAIDs, and both factors are important in other models of intestinal damage $(95,96)$.

The precise role of reduced mucosal prostaglandins in the pathogenesis of the ulceration in these animals also is uncertain because the drugs are given in doses far exceeding that needed to inhibit cyclo-oxygenase, and the temporal relationship between inhibition of cyclo-oxygenase and the macroscopic damage is all wrong (97). NSAID inhibition of prostoglandin generation may be more relevant at lower doses when the mucosa is not irreversibly damaged. Thus, under normal circumstances the action of prostaglandins is to increase bloodflow and mucus production and promote re-epithelisation which would normally heal a defect quickly (98). The lack of prostaglandin generation due to NSAIDs allows the damage to linger on for much longer than is seen, for instance, following hyperosmolar or alcohol-induced damage allowing greater mucosal exposure to luminal contents.

Thus, the specific effect of NSAIDs appears to be to uncouple oxidative phosphorylation and reduce ATP production, rendering the enterocytes energy deficient so that they lose integrity of the intercellular junctions. The effect is more prolonged and persistent because of the effect on prostaglandin production. In humans, extrapolating from animal data, this leads to a series of nonspecific events, common to all agents that disrupt the intestinal barrier, and exposes the mucosa to the luminal aggressive factors; in the small intestine these are mainly bile acids, pancreas secretions, ingested food and bacteria which, contrary to previous teaching, are present in significant numbers in the normal human small intestine (99). Bacterial invasion of the mucosa may be the main neutrophil chemoattractant in NSAID enteropathy in humans, similar to the situation in the rat, because metronidazole (a broad spectrum anaerobic antimicrobial) reduces both the severity of the enteropathy and the blood loss (100), further supporting the argument that the two are causally linked.

\section{INTESTINAL PERMEABILITY IN IBD}

Intestinal permeability is increased in the vast majority of patients with small intestinal involvement of Crohn's disease whether assessed as the straightforward urine excretion of orally administered ${ }^{51} \mathrm{CrEDTA}$ or as an excretion ratio of ${ }^{51} \mathrm{CrEDTA} / \mathrm{L}$ - rhamnose, lactulose/L-rhamnose or mannitol (101-112). The permeation of polyethylene glycol 400 varied showing increased or decreased permeation in Crohn's disease (113-115). There are, however, major problems with the PEG 400 permeation test (eg, up to $50 \%$ of the oral dose is absorbed). It cannot, therefore, be regarded as a test to assess the intestinal barrier function (116118). Furthermore, the basis by which the test was reintroduced, namely the claim of increased intestinal permeability in first degree relatives of patients with Crohn's disease (115), has not been substantiated (119) and appears to be due to an artificially low urine excretion in the apparently healthy control group. Approximately onehalf of the patients with colonic 
Crohn's disease have increased di/ monosaccharide urine excretion ratios, suggesting that the small intestine also is involved despite normal radiology (101). The permeability tests were not designed to test large-intestinal permeability, although some patients with extensive and active ulcerative colitis clearly have increased permeability with these tests. However, when instilled rectally, there is good evidence that the colitic mucosa is permeable to ${ }^{51} \mathrm{CrEDTA}$ with the increased permeability relating to disease activity $(120,121)$. The correlation between disease activity in Crohn's disease and increased intestinal permeability is not as clear (122). This is not surprising because of the noticeable lack of intercorrelations between any disease activity parameters in this disease $(123-128)$. The consensus is that in a given patient, permeability does correlate with disease activity but the measurements are only helpful clinically if performed sequentially in each individual. This is perhaps best shown in patients with Crohn's disease treated with an elemental diet in which case there is a significant reduction in intestinal permeability (112). More importantly, there is a significant correlation between the degree of normalization of intestinal permeability in these patients and the length of remission which they receive when they go on to a normal diet (112).

\section{INTESTINAL INFLAMMATION IN IBD}

The histopathological hallmarks of ulcerative colitis and Crohn's disease are well described but it is often forgotten that mucosal neutrophil accumulation is the defining histological feature of disease activity (129). This is exploited clinically by the fecal excretion of indium-111 labelled neutrophils which correlates well with histological indices of disease activity in ulcerative colitis (130-136). The correlation with clinical disease activity indices is more variable because some of these are not only dependent on subjective symptoms, but also are affected by factors that do not relate to acute inflammation directly. Successful therapeutic interventions are rapidly and reliably reflected by decreased fecal excretion of neutrophils in patients with IBD (112,122).

In the context of NSAID enteropathy and $1 B D$, the important question is what and where (luminal or mucosal) are the neutrophil chemoattractants? Indirect and direct evidence suggests that there is a luminal chemoattractant in Crohn's disease and a mucosal one in ulcerative colitis. Thus, mucosal neutrophils show no significant features of activation in Crohn's disease (while in ulcerative colitis this is clearly the case) (129). Therapeutic modalities directed toward altering the luminal milieu (enteral or parentral nutrition, bypass surgery) are at times spectacularly effective in Crohn's disease, but universally ineffective in ulcerative colitis. Lastly, a direct approach, correlating intestinal inflammation with tissue damage (as blood loss) shows that, for a given degree of inflammation, patients with ulcerative colitis bleed significantly more than patients with Crohn's disease (70). In as much as neutrophils can be viewed as specific suicidal chemodestructants, this indicates that the neutrophils are simply destined for the mucosa in ulcerative colitis and the lumen in Crohn's disease. This is supported by findings of increased number of formylmethionine-leucine-phenylalanine receptors on neutrophils from patients with Crohn's disease (137). It should be stressed that the neutrophil movement is not directly related to the mononuclear cell infiltrate, which is, of course, patchy and transmural in Crohn's disease and in any case is largely unaffected by disease activity. The nature of the chemoattractants (prostanoids, interleukins, microbial etc) are largely unknown in IBD. Although Stenson et al (10) suggest that it is predominantly leukotriene $\mathrm{B}_{4}$, it is but one of a number of possibilities. In NSAID enteropathy, where there is a significant correlation between inflammation and blood loss, there is circumstantial evidence that the main neutrophil chemoattractant is a metronidazole-sensitive microbe; indeed, it is suggested that it may be a part of the normal small intestinal faun and only gains access to the mucose because of NSAID-inducd increased in. testinal permeability (138).

\section{CAUSES AND POSSIBLE MECHANISMS OF RELAPSE IN IBD}

Relapses of IBD are often caused by NSAID ingestion, alcohol binges, infection and stress. At first sight these appear too diverse to have anything in common. However NSAIDs, alcohol and infection all increase intestinal permeability in humans $(71,139,140)$. Whether stress affects intestinal permeability is a contentious issue that cannot be studied easily in humans. Psychiatric patients are purported to have increased intestinal permeability (141), although this has not been confirmed (142). Stress of various kind (cold, near drowning, etc) potentiates damage by exogenous agents in the experimental animal and there is little doubt that stress causes exacerbation of many diseases. MacQueen et al (143) recently produced convincing evidence that mucosal mast cell function (activation and mast cell protease 11) is profoundly affected by neural stimuli such as is seen in classic Pav. lovian conditioning. If so, the important link and interaction between the central nervous system and the gastrointestinal tract in patients with Crohn's disease becomes relevant as mast cells appear to be important determinants of the leakiness of the mucosa to ${ }^{51} \mathrm{CrEDTA}$ and macromolecules (144,145).

How does the observed increased intestinal permeability due to NSAIDs compare and tie up with the possible relapse of Crohn's disease? NSAID-induced intestinal permeability sets off a cascade of nonspecific events, discussed in the previous section, which leads to NSAID enteropathy. Quantitatively the permeability changes with NSAIDs are identical with those seen following alcohol ingestion, intestinal infections and in Crohn's disease, However, the resulting neutrophil response to the mucosal exposure of luminal chemoattractants in Crohn's disease is quite different and far greater 
than that seen in any other intestinal disease apart from ulcerative colitis. Hence, instead of recruiting a mere platoon of neutrophils to destroy the chemoattractant, patients with Crohn's disease send in an entire army. This supports Sartor's suggestion that there may be a problem with down regulation of the inflammatory response in IBD. A further clue to support the case comes from sequential studies in patients with Crohn's disease treated with an elemental diet (146). Clinical remission can be achieved in 80 to $90 \%$ of patients with active disease by stopping all normal food intake and substituting this with a liquid elemental diet. Clinical improvement usually is evident within four to seven days, and by two to four weeks there is a significant and drastic reduction in the fecal excretion of indium-111 neutrophils as well as other less specific markers of acute inflammation (112). However, interleukin-2 receptor levels in serum are persistently high and unaffected by this treatment, indicative of continuous $\mathrm{T}$ cell activation (147). Furthermore, as the beneficial effect of elemental diets in patients with Crohn's disease appear to be unrelated to any direct effect on nutritional or immunological factors, the above supports the idea that relapse of the disease is indeed the inevitable, nonspecific consequence of a disrupted intestinal

\section{REFERENCES}

1. Donaldson RM. Crohn's disease. In: Sleisenger MH, Fortran JS, eds. Gastrointestinal disease. Philadelphia, WB Saunders 1989;1327-58,

2. Wakefield AJ, Sawyer AM, Dhillon AP, Pittilo RM, Rowles PM, Lewis AAM, et al. Pathogenesis of Crohn's disease: multifocal gastrointestinal infarction, Lancet 1989;ii,1057-62.

3. Stevens TRJ, James JP, Simmonds NJ, McCarthy DA, Laurenson IF, Maddison PJ, et al. Circulating von Willebrand factor in inflammatory bowel disease. Gut 1992;33:502-506. 4. Chiodini RJ. Crohn's disease and the mycobacteriosis - a review and comparison of two disease entities. Clin Microbial Rev 1989;2:90-117.

5. McFadden JJ, Butcher PD, Chiodini R, Hermon-Taylor J. Crohn's disease isolated mycobacteria are identical to Mycobacterium paratuberculosis as determined by DNA probes that mucosa. The underlying Crohn's disease diathesis is simply causing an exaggerated response. The precise reason and mechanism of the increased immune reactivity to intestinal antigens in Crohn's disease (hyperreactivity, loss of down regulation, etc) will provide clues to the etiology of the disease but these studies are still in their infancy. The idea of a nonspecific sequence of events as the clinically important cause of relapse in Crohn's disease is important and supported by other findings. The local humoral antibody response in patients with Crohn's disease, assessed by analysis of mucosal immunoglobulins, appears to be directed against the normal intestinal microbial flora; mucosal immunoglobulin G production in particular appears to relate to disease activity (ie, relapse) in Crohn's disease (unpublished data). Additionally it provides a logical explanation for the finding that patients undergoing treatment with elemental diets whose intestinal permeability is restored to normal enjoy longer remissions than those who have persistent (albeit improved) increased intestinal permeability. Supporting data are arguably quite limited. This, in part, is due to several factors: first, the lack of valid criteria of active disease on a mucosal level in most published studies; second, the fact that few studies address sequential alterations in

distinguish between mycobacterial species. J Clin Microbial 1987;25:796-801.

6. Hermon-Taylor J. Mycobacterium paratuberculosis, environmental mycobacteria, and Crohn's disease. In: Peters TJ, ed. The Cell Biology of Inflammation in the Gastrointestinal Tract. Hull: Corners Publications, 1990;323-42.

7. Elson CO, Kagnoff MF, Fiocchi C, Befus AD, Targen S. Intestinal immunity and inflammation: recent advances. Gastroenterology 1986;91:746-8.

8. Allan RN, Hodgson HJF. Inflammatory bowel disease. In: Pounder RE, ed. Recent Advances in Gastroenterology-7. Edinburgh: Churchill Livingstone, 1988;1:21.

9. Sharon P, Stenson WF. Enhanced synthesis of leukotriene B4 by colonic mucosa in inflammatory bowel disease. Gastroenterology 1984;86:452-60. observed parameters in patients with IBD (which often brings out findings otherwise hidden in grouped data); and third, the fact that many are content with the assay of a single phenomena rather than taking an integrated approach to study the possible interaction of the various parameters, and comparing and contrasting these directly with that of other intestinal diseases.

\section{CONCLUSIONS}

The use of a battery of new, accurate and highly specific functional techniques to study the human gastrointestinal tract provides much new information on pre-existing disease and has led to the characterization of new small intestinal disease where none were thought to exist. Logical extrapolation of experimental findings in humans allows a sensible pathogenic framework for Crohn's disease to be described, which clearly distinguishes between the specific and nonspecific events that determine the clinical features of the disease. The authors make no apologies for the apparent simplicity of the hypothesis for this makes it amiable for further testing, and point out that precious little progress has been made by armchair speculation with formulation of hopelessly complex cascade diagrams on the molecular interaction of immunological cells and inflammatory mediators.

10. Stenson WF. Eicosanoids in inflammatory bowel disease with special reference to leukotriene $B_{4}$. In: Peters T], ed. The Cell Biology of Inflammation in the Gastrointestinal Tract. Hull: Corners Publications, 1990;273-81.

11. Sartor RB. The role of intestinal microflora in initiation and perpetuation of inflammatory bowel disease. In: Williams CN, ed. Trends in Inflammatory Bowel Disease. Falk Symposium 56. Dordrecht: Kluwer Academic Publishers, 1991;17-27.

12. Bjarnason I, Williams P, So A, Zanelli G, Levi AJ, Gumpel MJ, Peters T], Ansell B. Intestinal permeability and inflammation in rheumatoid arthritis; Effects of nonsteroidal anti-inflammatory drugs. Lancet. 1984;ii:1171-4.

13. Bjarnason I, Zanelli G, Smith T, Prouse P, De Lacey G, Gumpel MJ, Levi AJ. Nonsteroidal antiinflammatory drug induced inflammation in 
humans. Gastroenterology 1987;93:480-9.

14. Bjarnason I, Macpherson A. The changing gastrointestinal side effect profile of non-steroidal antiinflammatory drugs. A new approach for the prevention of a new problem. Scand J Gastroenterol 1989;24 (Suppl 163):56-64.

15. Bjarnason I, Smethurst P, Hayllar J, Levi AJ. NSAID enteropathy; The main site of chronic blood loss in patients on NSAIDs. Gut 1990;91:A1203.

16. Morris J, Madhok R, Sturrock RD, Capell HA, Mackenzie JF. Enteroscopic diagnosis of small bowel ulceration in patients receiving nonsteroidal anti-inflammatory drugs. Lancet 1991;337:520,

17. Bjarnason I, Zanelli G, Prouse P, Smethurst P, Smith T, Levi S, Gumpel MJ, Levi AJ. Blood and protein loss via small intestinal inflammation induced by nonsteroidal anti-inflammatory drugs. Lancet 1987;ii:711-4.

18. Lang J, Price AB, Levi AJ, Burk M, Gumpel JM, Bjarnason I. Diaphragm disease - the pathology of non-steroidal anti-inflammatory drug induced small intestinal strictures. J Clin Path 1988;41:516-26.

19. Bjarnason I. Non-steroidal antiinflammatory drug induced small intestinal inflammation in man. In: Pounder R, ed. Recent Advances in Gastroenterology-7. London:

Churchill Livingstone, 1988:23-46.

20. Bjarnason I, Peters TJ. Intestinal permeability, NSAID enteropathy and inflammatory bowel disease. Gut 1991;30:22-8.

21. Bjarnason I, Peters TJ. Helping the mucosa make sense of macromolecules. Gut 1987;28:1057-61.

22. Kaufman HJ, Taubin HL. NSAID activate quiescent inflammatory bowel disease. Ann Int Med 1987;1107:513-6.

23. Rampton DS, Sladen G GE. Relapse of ulcerative proctocolitis during treatment with NSAID. Postgrad Med J 1981;157:297-9.

24. Rampton DS, McNeil NI, Sarner M. Analgesic ingestion and other factors preceding relapse in ulcerative colitis. Gut 1983;124:187-9.

25. Riley SA, Mani V, Goodman MJ, Lucas S. Why do patients with ulcerative colitis relapse? Gut 1990;31:179-83.

26. Rampton DS, Sladen G. Prostaglandin synthesis inhibition in ulcerative colitis. Flurbiprofen compared with conventional treatment. Prostagiandins 1981;21:417-25.

27. Campieri M, Franchi LGA, Bazzocchi $\mathrm{G}$, et al. Prostagiandins, indomethacin and ulcerative colitis.
Gastroenterology 1980;79:193.

28. Hawkey CJ, Rampton DS. Prostaglandins and the gastrointestinal mucosa. Are they important in its function, disease or treatment? Gastroenterology 1985;89:1162-88.

29. Rask-Madsen J, Bukhave K, Laursen LS, Lauritsen K. Eicosanoids in inflammatory bowel disease Physiology and pathology. In: Peters TJ, ed. The Cell Biology of Inflammation in the Gastrointestinal Tract. Hull: Corners Publication, 1990;255-71.

30. Wright $\mathrm{V}$, Watkinson $\mathrm{G}$. The arthritis of ulcerative colitis. Br Med J 1965;ii:479-86.

31. Ravi S, Keat AC, Keat ECB. Colit is caused by NSAID. Postgrad Med J 1986;62:773-6.

32. Clements D, Williams GT, Rhodes ]. Colitis associated with ibuprofen. Br Med J 1990;301:987.

33. Tanner AR, Raghunat H. Colonic inflammation and NSAID administration. Digestion 1988;41:116-20.

34. Pearson DJ, Stones NA, Bentley SJ, Reid $\mathrm{H}$. Proctocolitis induced by salicylate and associated with asthma and recurrent nasal polyps. Br Med J 1983;287:1675.

35. Rutherford D, Stockdill G, Hammer-Hodges DW, Ferguson A. Proctocolitis induced by salicylates. Br Med J 1984;1288:794.

36. Phillips MS, Fehilly B, Stewart S, Dronfield WM. Enteritis and colitis associated with mefenamic acid. Br Med J 1983;1287:1626-7.

37. Edwards AL, Heagerty AM, Bing RF. Enteritis and colitis associated with mefenamic acid. Br Med J 1983;287:1627.

38. Rampton DS, Trapping PJ. Enteritis and colitis associated with mefenamic acid. Br Med J 1983;287:1627.

39. Hall RI, Petty AH, Cobden I, Lendrum R. Enteritis and colitis associated with mefenamic acid. Br Med J 1983;287:1182.

40. Isaacs PET, Sladen G GE, Filipie I. Mefenamic acid enteropathy. J Clin Pathol 1987;140:121-7.

41. Williams R, Glazier G. Enteritis and colitis associated with mefenamic acid. Br Med J 1983;287:1627.

42. Langman MJS, Morgan L, Worrall A. Use of anti-inflammatory drugs by patients with small or large bowel perforation and haemorrhage. $\mathrm{Br}$ Med J 1985;290:347-9.

43. Mielants H, Veys EM, Covelier C, De Vos M, Botelberge L. HLA-B27 related arthritis and bowel inflammation. Part 2. Ileocolonoscopy and bowel histology in patients with HLA-B27 related arthritis.
J Rheumatol 1984;112:294-8.

44. Mielants H, Veys EM, Covelier C, De Vos M. Ileocolonoscopic findings in seronegative spondylarthropathies. Br J Rheumatol 1988;27(Suppl 11):95-105.

45. Mielants H, Veys EM, De Vos M, Covelier C. Gut inflammation in the pathogenesis of idiopathic forms of reactive arthritis and in the peripheral joint involvement of ankylosing spondylitis. In: Mielants H, Veys EM, eds. Spondylarthropathies. Involvement of the gut. Amsterdam: Excerpta Medica, 1987:11-21.

46. Woolf DL. Indomethacin suppositories. Br Med J 1965;i: 1497.

47. Berry $H$, Seinson D, Jones $H$, Hamilton EBD. Indomethacin and naproxen suppositories in the treatment of rheumatoid arthritis. Ann Rheum Dis 1978;37:370-2.

48. Wright V, Hopkins R. A note on indomethacin suppositories in rheumatic conditions. Rheumatol Rehab 1979;18:186-7.

49. Levy N, Gaspar E. Rectal bleeding and indomethacin suppositories. Lancet 1975;i: 77 .

50. Lanthier P, Detry R, Debongnie JC, Mahieu P, Vanheuverzwyn R. Solitary rectal lesions due to suppositories containing acetylsalicylic acid and paracetamol. Gastroenterol Clin Biol 1987;111:250-3.

51. Beardon PHG, Brown SV, Mcdevitt DG. Gastrointestinal events in patients prescribed NSAIDs - A controlled study using record linkage in Tayside. Q J Med 1989;71:497-505.

52. Cockel R. NSAIDs - should every prescription carry a government health warning? Gut 1987;28:515-8.

53. Armstrong CP, Blower AC.

Non-steroidal anti-inflammatory drugs and life threatening complications of peptic ulceration. Gut 1987;28:527-32

54. Wilkinson PC. Leucocyte locomotion: determinants of locomotor capacity, chemotaxis and chemokinesis. In: Peters TJ, ed. The Cell Biology of Inflammation in the Gastrointestinal Tract. Hull: Corners Publications, 1990;15-27.

55. Malech MI, Callin JI. Neutrophils in human disease. N Engl J Med 1987;317:687-94.

56. Weiss SJ. Tissue destruction by neutrophils. N Engl J Med 1989;1320:365-76.

57. Segall AW. The electron transport chain of the microbicidal oxidase of phagocytic sells and its involvement in the molecular pathology of chronic granulomatous disease. In: Peters T], ed. The Cell Biology of Inflammation in the Gastrointestinal Tract. Hull: Corners Publications, 1990;51-73. 
58. Sturges HF, Krone CL. Ulcers and strictures of the jejunum in a patient on long term indomethacin therapy. Am J Gastroenterol 1973;59:162-9.

59. Venturatos SG, Hines C, Blalock JB. Ulceration of the small intestine in a patient with coeliac disease. South Med J 1984;77:520-2.

60. Neoptolemos JP, Locke TJ. Recurrent small bowel obstruction associated with phenylbutazone. $\mathrm{Br}$ J Surg 1983;70:244-5

61. Madhok R, Mackenzie JA, Lee FD, Bruckner FE, Terry TR, Sturrock RD. Small bowel ulceration in patients receiving NSAIDs for rheumatoid arthritis. Q J Med 1986;58:53-8.

62. Saverymuttu SH, Thomas A, Grundy A, Maxwell JD. Ileal stricturing after long term indomethacin treatment. Postgrad Med J 1986;162:267-8.

63. Sukumar L. Recurrent small bowel obstruction with piroxicam. Br J Surg 1987; 174:186.

64. Johnson F. Recurrent small bowel obstruction with piroxicam. Br J Surg 1987;174:654. (Lett)

65. Bjarnason I, Price AB, Zanelli G, et al. Clinicopathological features of nonsteroidal anti-inflammatory druginduced small intestinal strictures. Gastroenterology 1988;94:1070-4.

66. Huber T, Ruchti C, Halter F. Nonsteroidal antiinflammatory druginduced colonic strictures: A case report. Gastroenterology 1991;100:1119-22.

67. Dybdahl JH, Daae LNW, Larsen S, Myren J. Occult faecal blood loss determined by a $51 \mathrm{Cr}$ method and chemical tests in patients referred for colonoscopy. Scand J Gastroenterol 1984;119:245-54.

Bellamy JEC, Nielsen NO. Immune mediated emigration of neutrophils into the lumen of the small bowel. Infect Immunity 1974;9:615-9.

69. Sartor RB, Cromartie WJ, Powell DW, Schwall JH. Granulomatous enterocolitis induced in the rat by purified bacterial cell wall fragments. Gastroenterology 1985;89:587-95.

70. Teahon K, Levi AJ, Bjarnason I. Intestinal inflammation and bleeding in NSAID enteropathy and inflammatory bowel disease. Gut 1990;31:A593.

71. Bjarnason I, Williams P, Smethurst Pm Peters TJ, Levi AJ. The effects of NSAID and prostaglandins on the permeability of the human small bowel. Gut 1986;27:1292-7.

12. Bjarnason I, Smethurst P, Clarke P, Menzies IS, Levi AJ, Peters TJ. Effect of prostaglandins on indomethacin induced increased intestinal permeability in man. Scand J Gastroenterol 1989;29(Suppl
164):97-103.

73. Bjarnason I, Smethurst P, Fenn CG, Lee CF, Menzies IS, Levi AJ. Misoprostol reduces indomethacin induced changes in human small intestinal permeability. Dig Dis Sci 1989;34:407-11.

74. Jenkins RT, Rooney PJ, Jones DB, Bienenstock J, Goodacre RC. Increased intestinal permeability in patients with rheumatoid arthritis. A side effect of oral NSAID therapy? Br J Rheumatol 1987;26:103-7.

75. Auer 10, Habscheid W, Hiller S, Gerhards W, Eilles C. Nicht-steroidale antiphlogistika erohen die darmpermeabilitat. Deut Med Wochenscr 1987;112:1032-7.

76. Aabakken C, Osnes M. 51-Cr ethylenediaminetetraacetic acid absorption test. Effects of naproxen, an NSAID. Scand J Gastroenterol 1990;125:917-24.

77. Bjarnason I, Fehilly B, Smethurst P, et al. The importance of local versus systemic effects of NSAID to increase small intestinal permeability in man. Gut 1991;132:275-7.

78. Bjarnason I, Smethurst P, Walker F, Macpherson A, McElnay SC, Pearson $\mathrm{P}$, Menzies IS. Glucose and citrate reduce the permeability changes caused by indomethacin. Gastroenterology. (In press)

79. Bjarnason I. Intestinal permeability barriers. In: Peters TJ, ed. The Cell Biology of Inflammation in the Gastrointestinal Tract. Hull: Corners Publication, 1990;127-42.

80. Davin JC, Forget $\mathrm{P}$, Mahieu PR. Increased intestinal permeability to $(51 \mathrm{Cr})$ EDTA is correlated with $\operatorname{Ig} \mathrm{A}$ complex-plasma levels in children with $\operatorname{Ig} \mathrm{A}$-associated nephropathies. Acta Paediatr Scand 1988:77:118-24.

81. Ramage JK, Stanisz A, Scicchitano R, Hunt RH, Perdue MH. Effects of immunologic reaction on rat intestinal epithelium. Correlation of increased intestinal permeability to chromium 51 labelledethylenediaminetetraacetic acid and ovalbumin during acute inflammation and anaphylaxis. Gastroenterology 1988;194:1368-75.

82. Ferry DM, Butt TJ, Broom MF, Hunter J, Chadwick VS. Bacterial chemotactic oligopeptides and the intestinal mucosal barrier. Gastroenterology 1989;97:61-7.

83. Davies GR, Rampton DS. The pro-drug sulindac may reduce the risk of intestinal damage associated with the use of conventional non-steroidal anti-inflammatory drugs. Anment Pharmacol Therap 1991;5:593-8.

84. Hayllar J, Somasundaram S, Sarathchandra P, Levi AJ, Bjarnason I. Early cellular events in the pathogenesis of NSAID enteropathy in the rat. Gastroenterology 1991:100:A216.

85. Somasundaram S, Hayllar J, Macpherson A, Bjarnason I. The biochemical basis of intestinal damage due to NSAIDs. A review and a hypothesis. (In press)

86. Somasundaram S, Macpherson AJ, Hayllar J, Saratchandra P, Bjarnason I. Enterocyte mitochondrial damage due to NSAID in the rat. Gut 1992;33(Suppl):S5.

87. Kent TH, Cardeli RM, Stanler FU. Small intestinal ulcers and intestinal flora in rats given indomethacin. Am J Pathol 1969;54:237-45.

88. Robert A. Cytoprotection by prostaglandins. Gastroenterology 1975; 177:761-7.

89. Robert A, Asano T. Resistance of germ free rats to indomethacin-induced intestinal lesions. Prostaglandins 1977;114:331-41.

90. Satoh H, Guth PH, Grossman MI. Role of bacteria in gastric ulceration produced by indomethacin in the rat. Cytoprotective action of antibiotics. Gastroenterology 1983;184:483-9.

91. Del Soldato P, Foschi D, Benoni G, Velo GP. Early and late phases in the formation by anti-inflammatory drugs of intestinal lesions in the rat. In: Rainsford KD, Velo GP, eds. Side Effects of Anti-inflammatory Drugs. Lancaster: MTP Press, 1987;67-81.

92. Brodie DA, Cook PG, Bauer BJ, Dagleg E. Indomethacin-induced intestinal lesions in the rat. Toxicol and Appl Pharmacol 1970;17:615-24.

93. Wallace JL, Keenan CM, Granger DN. Gastric ulceration induced by nonsteroidal anti-inflammatory drugs is a neutrophil dependent process. Am J Physiol 1990;1259:G462-7.

94. Wallace JL, Arfors KE, McKnight GW. A monoclonal antibody against the CD 18 leucocyte adhesion molecule prevents indomethacininduced gastric damage in the rabbit. Gastroenterology 1991;100:878-83.

95. Granger DN, Benoit JN, Suzuki M, Grisham MB. Leucocyte adherence to venular endothelium during ischemia perfusion. Am J Physiol 1985;257:G683-8.

96. Granger DN, Zimmerman BJ, Seikizuka E, Grisham MB. Intestinal microvascular exchange in the rat during luminal perfusion with $\mathrm{N}$-formyl-methionyl-leucylphenylalanin. Gastroenterology 1988;194:673-81.

97. Whittle BJR. Temporal relationship between cyclooxygenase inhibition, as measured by prostacyclin biosynthesis, and gastrointestinal damage induced by indomethacin in the rat. 
Gastroenterology 1981;180:94-8.

98. Hayllar J, Macpherson A, Bjarnason I. Gastroprotection and nonsteroidal anti-inflammatory drugs. Drug Safety 1992:17:86-105.

99. Stephen AM. Effect of food on the intestinal microflora, In: Hunter JO, Alun lones V, eds. Food and the Gut. London: Bailliere Tindall, 1985;57-77.

100. Bjarnason I, Turner-Stokes L, Smethurst P, Levi AJ, Gumpel MJ. Metronidazole reduces inflammation in NSAID enteropathy. Gastroenterology 1990;98:A439.

101. Ukabam SO, Clamp JR, Cooper BT. Abnormal small intestinal permeability to sugars in patients with Crohn's disease of the terminal ileum and colon. Digestion 1983;27:70-4.

102. Andre F, Andre C, Emery Y, Foricon J, Descos L, Minaire Y. Assessment of the lactulose-mannitol test in Crohn's disease. Gut 1988;129:511-5.

103. Murphy MS, Eastham EJ, Nelson R, Pearson ADJ, Laker MF. Intestinal permeability in Crohn's disease. Arch Dis Child 1989;64:321-5.

104. Pearson ADJ, Eastham EJ, Laker MF, Ceaft AW, Nelson R. Intestinal permeability in children with Crohn's disease and coeliac disease. Br Med J 1982;1285:20-1.

105. Sanderson IR, Boulton P, Menzies IS, Walker-Smith JA. Improvement of abnormal lactulose/rhamnose permeability in active Crohn's disease of small bowel by elemental diet. Gut 1987;28:1073-6.

106. Bjarnason I, O'Morain C, Levi AJ, Peters TJ. Absorption of 51-Chromium-labelledethylenediamineterraacetate in inflammatory bowel disease. Gastroenterology 1983;85:318-22

107. O'Morain C, Abelow CA, Cheru LR, Fleischner GM, Das KM. 51-CrEDTA test: A useful test in the assessment of inflammatory bowel disease. J Lab Clin Med 1986;1108:430-5.

108. Casellas F, Aguade S, Soriano B, Accarino A, Molero J, Guarner L. Intestinal permeability to $99 \mathrm{mTc}$ diethyl enetetriaminopentaacetic acid in inflammatory bowel disease. Am ] Gastroenterol 1986;81:767-70.

109. Pironi L, Migliolti M, Ruggeri E, et al. Relationship between intestinal permeability to $51 \mathrm{Cr}$ EDTA and inflammatory activity in asymptomatic patients with Crohn's disease. Dig Dis Sci 1990;35:582-8.

110. Jenkins RT, Ramage JK, Jones DB, Collins SM, Hunt RH. Small bowel and colonic permeability to $51 \mathrm{Cr}$ EDTA in patients with active inflammatory bowel disease. Clin Invest Med 1988;111:151-5.

111. Resnik RH, Royal H, Marshall W,
Barron R, Werth T. Intestinal permeability in gastrointestinal disorders. Use of $99 \mathrm{mTc}$ DTPA. Dig Dis Sci 1990;135:205-211.

112. Teahon K, Smethurst P, Pearson M, Levi AJ, Bjarnason I. The effect of elemental diet on intestinal permeability and inflammation in Crohn's disease. Gastroenterology 1991;101:84-9.

113. Hollander D. Crohn's disease - A permeability disorder of tight junctions. Gut 1988;29:1621-4.

114. Olaison G, Sjodhal R, Tageson C. Abnormal intestinal permeability in Crohn's disease. Scand J Gastroenterol 1990;25:321-8.

115. Hollander D, Vadheim CM, Breththotz E, Peterson GM, Delahunty TJ, Rutter J. Increased intestinal permeability in Crohn's disease patients and their first degree relatives: an etiological factor? Ann Intern Med 1986;105:883-5.

116. Menzies IS. Transmural passage of inert molecules in health and disease. In: Skadhauge E, Heinize K, eds. Intestinal Absorption and Secretion. Falk Symposium 36, Lancaster Press 1984;527-43.

117. Cooper BT. Tests of intestinal permeability in clinical practice. J Clin Gastroenterol 1984;6:499-501.

118. Maxton DG, Bjarnason I, Reynolds AP, Catt SD, Peters TJ, Menzies IS. Lactulose, 51-Cr labelled ethylenediaminetetraacetate, L-rhamnose and polyethylene glycol 400 as probe markers for assessment of in vivo of human intestinal permeability. Clin Sci 1986;71:71-80.

119. Teahon K, Smethurst P, Levi AJ, Menzies IS, Bjarnason I. Intestinal permeability in patients with Crohn's disease and their first degree relatives. Gut 1992:33:320-3.

120. Rask-Madsen J, Schwartz M. Absorption of $51 \mathrm{Cr}$-EDTA in ulcerative colitis following rectal instillation. Scand J Gastroenterol 1970;5:361-8.

121. O'Morain C, Abelon AL, Chervli LR, Fleischer GM, Das K. 51 Cr EDTA test - A useful test in the assessment of inflammatory bowel disease. J Lab Clin Med 1986;108:430-5.

122. Teahon K, Smethurst P, Levi AJ, Menzies IS, Bjarnason I. Intestinal permeability in Crohn's disease and its relation to disease activity. Submitted.

123. Maratka Z. Crohn's disease activity indexes: Need for distinguishing activity from severity. Hepato-Gastroenterol 1981;28:187-8.

124. Best WR, Becktel JM, Singleton JW, Kern F. The development of a Crohn's disease activity index. Gastroenterology 1975;70:439-44.
125. DeBombal FT, Softley A. IOIBD report No 1. Observer variation in calculating indices of severity and activity in Crohn's disease. Gut 1987;28:474-81.

126. Gomes P, DuBoulay C, Smith CL, Holdstock G. Relationship between disease activity and colonoscopic findings in patients with colonic inflammatory bowel disease. Gut 1986;27:92-5.

127. Modiguani R, Mary JY, Simon JF, Cortot A, Soule JC, Gendre JP, Rene E, D'Etude G. Clinical biological and endoscopic picture of attacks of Crohn's disease. Gastroenterology 1990;198:811-8.

128. Brignola $\mathrm{C}$, Langrachi GA, Campieri M, Bazzocchi G, Devoto M, Boni P, Farruggia P, Veggetti S, Tragnone A. Importance of laboratory parameters in the evaluation of Crohn's disease activity. J Clin Gastroenterol 1986;8:245-8.

129. Dvorak AM. Ultrastructural pathology of Crohn's disease. In: Goebell H, Peskar BM, Malchow H, eds. Inflammatory Bowel Diseases - Basic Research and Clinical Implications. Lancaster: MTP Press Ltd.,Falk symposium 46, 1988;3:41.

130. Saverymuttu SH,Peters AM, Lavendet JP, Hodgson HJ, Chadwick VS. Indium-111 autologous leucocytes in inflammatory bowel disease. Gut 1983;24:293-9.

131. Stein DT, Gray GM, Gregory PB, Anderson M, Goodwin DA,

McDougal IR. Location and activity of ulcerative and Crohn's colitis by indium-111 leucocyte scan.

Gastroenterology 1983;184:388-93.

132. Leddin DJ, Paterson WG, DaCosta LR et al. Indium-111-labeled autologous leucocyte imaging and faecal excretion. Dig Dis Sci 1987;132:377-87.

133. Fishback W, Becker W, Mossner J, Koch W, Reiners C. Faecal alpha-1 antitrypsin and excretion of indium-111 granulocytes in assessment of disease activity in chronic inflammatory bowel diseases. Gut 1987;28:386-93.

134. Saverymuttu SH, Peters AM, Lavender JP, Hodgson H, Chadwick VS. Quantitative faecal indium-111 labelled leucocyte excretion assessment of disease activity in Crohn's disease. Gastroenterology 1983;85:1333-9.

135. Saverymuttu SH, Camilleri M, Rees H, Cavender TP, Hodgson HJF. Indium-111 granulocyte scanning comparison with colonoscopy histology and faecal indium-111 excretion in assessing disease extent and activity in colitis. Gastroenterology 1986;190:1121-8. 
136. Chadwick VS. Clinical investigation of patients with malabsorption and diarrhoea. In: Bouchier IAD, Allan RN, Hodgson HJF, Keighley MRB, eds. Textbook of Gastroenterology. London: Bailliere Tindall, 1984;428-41.

137. Anton PA, Targan SR, Shanahan F. Increased neutrophil receptors for and response to the proinflammatory bacterial peptide formyl-methionylleucylphenylalanine in Crohn's disease. Gastroenterology 1989;97:20-8.

138. Bjarnason I, Hayllar J, Smethurst P, Price AB, Gumpel MJ. Metronidazole reduces intestinal inflammation and blood loss in non-steroidal anti-inflammatory drug induced enteropathy. Gut. (In press)

139. Noone C, Menzies IS, Banatvala JE, and Scopes JW. Intestinal permeability and lactose hydrolysis in human rotaviral gastroenteritis assessed simultaneously by non-invasive differential sugar permeation. Eur J Clin Invest 1986;16:217-25.

140. Bjarnason I, Ward K, Peters TJ. The leaky gut of alcoholism: Possible route of entry for toxic compounds. Lancet $1984 ; i: 179-82$.

141. Wood NC, Hamilton I, Axon ATR, et al. Abnormal intestinal permeability in chronic psychiatric disorders. $\mathrm{Br}$ J Psych 1987;150:853-5.

142. Lambert MT, Bjarnason I, Connally J, Crow TJ, Johnstone EC, Peters TJ, Smethurst P Small intestinal permeability in schizophrenia. $\mathrm{Br}$ ] Psych 1989;155:619-22.

143. MacQueen G, Marshall J, Perdue M, Siegel S, Bienenstock J. Pavlovian conditioning of rat mucosal mast cells to secrete rat mast cell protease 11 . Science 1989;243:83-5.
144. D'Inca R, Ramage J, Hunt RH, Perdue $\mathrm{MH}$. Antigen-induced mucosal damage and restitution in the small intestine of the immunised rat. Int Arch Allergy Appl Immunol 1990;191:270-7.

145. Crowe SE, Sestini P, Perdue MH. Allergenic reactions of rat jejunal mucosa. Gastroenterology 1990;99:74-82.

146. Teahon K, Bjarnason I, Pearson M, Levi AJ. Ten years experience with elemental diet in the management of Crohn's disease. Gut 1990;131:1133-7.

147. Duane PD, Teahon K, Crabtree JE, Levi AJ, Heatley RV, Bjarnason I. The relationship between nutritional status and serum soluble interleukin 2 receptor concentrations in patients with Crohn's disease treated with elemental diet. Clin Nutr 1991;10:222-7. 


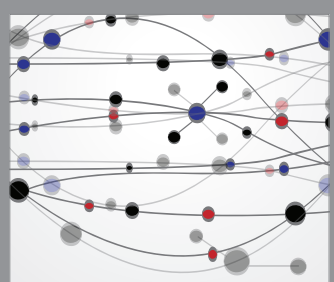

The Scientific World Journal
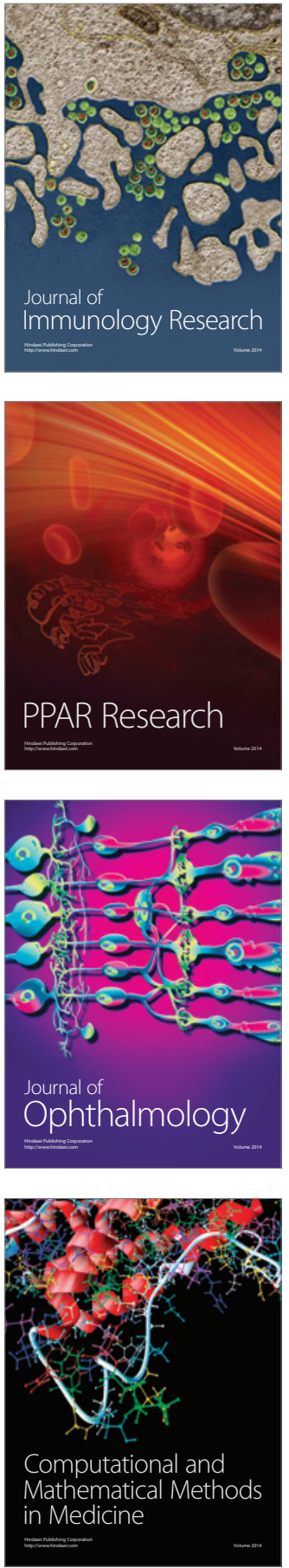

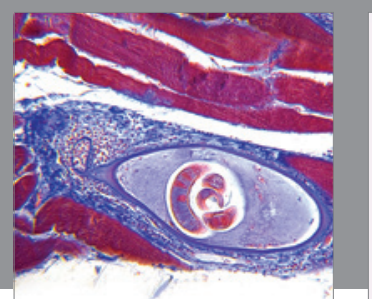

Gastroenterology Research and Practice

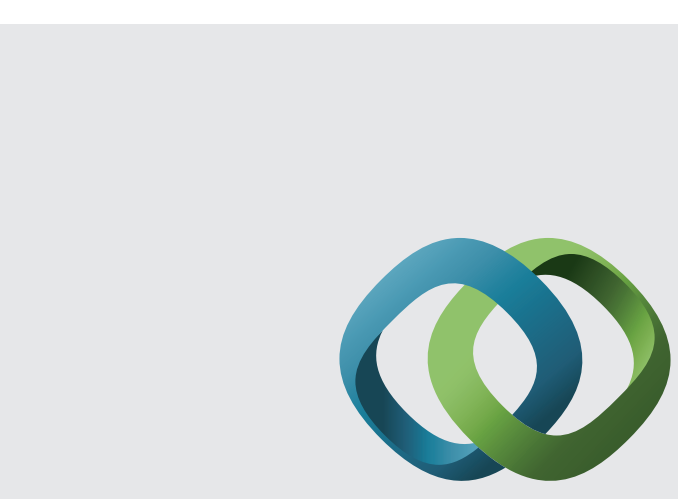

\section{Hindawi}

Submit your manuscripts at

http://www.hindawi.com
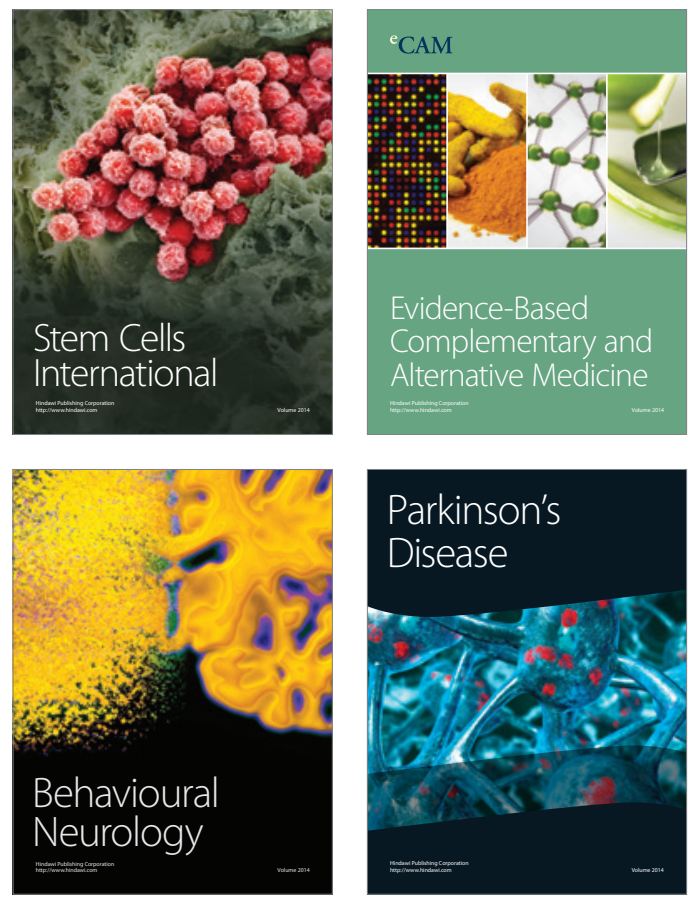
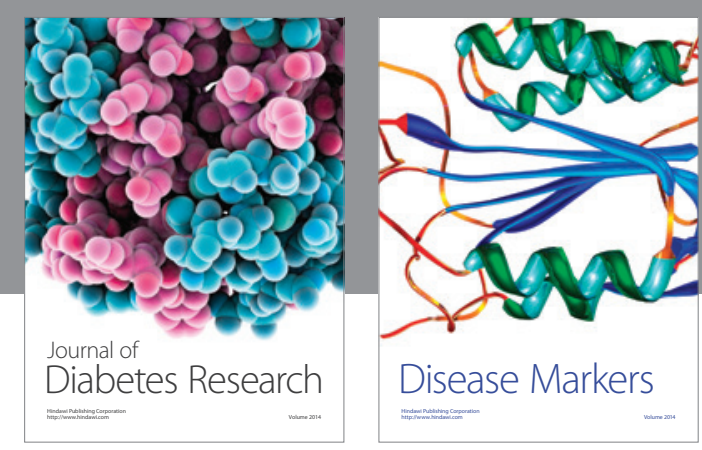

Disease Markers
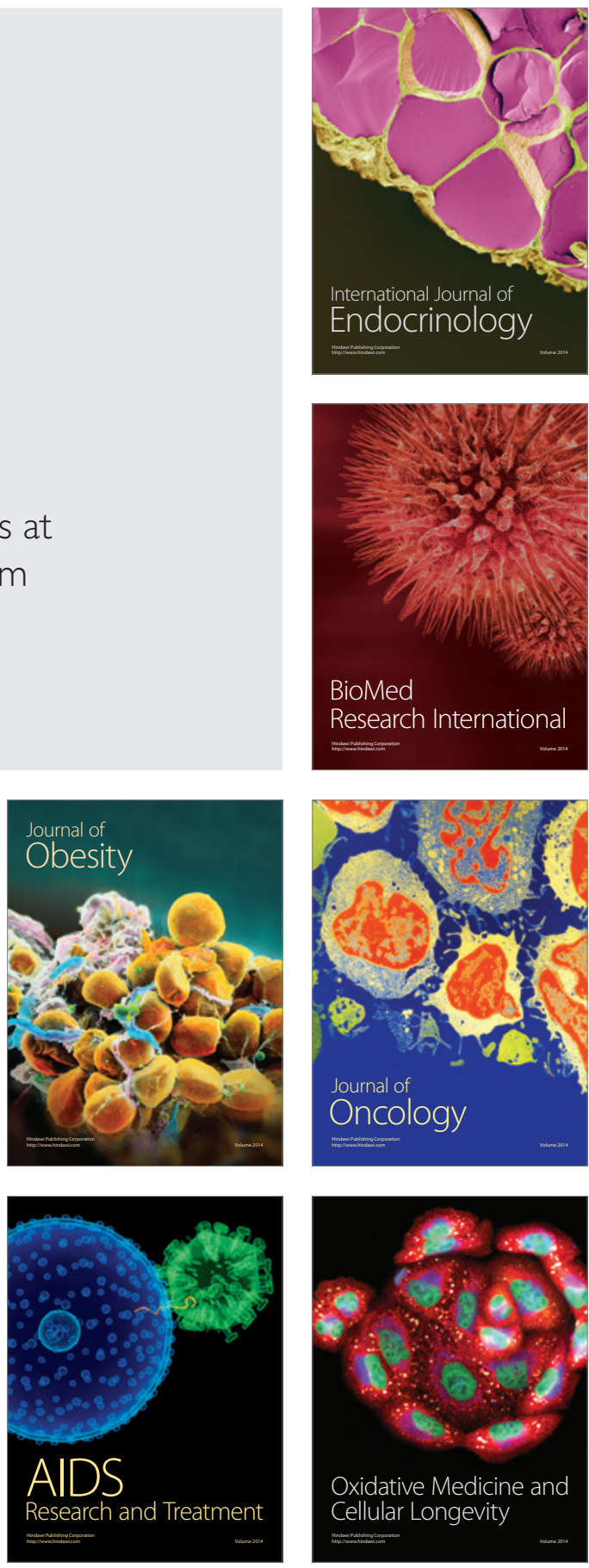